\title{
High Throughput Screening for Expanded CTG repeats in Myotonic Dystrophy Type 1 Using Melt Curve Analysis
}

Russell J Butterfield ${ }^{1}, 2$, Carina Imburgia ${ }^{1}$, Katie Mayne ${ }^{1}$, Tara Newcomb ${ }^{1}$, Diane M Dunn $^{3}$, Brett Duval ${ }^{3}$, Marcia L Feldkamp ${ }^{1}$, Nicholas E Johnson ${ }^{4}$, and Robert B Weiss ${ }^{3}$

${ }^{1}$ Department of Pediatrics, University of Utah, Salt Lake City, UT ${ }^{2}$ Department of Neurology, University of Utah, Salt Lake City, UT ${ }^{3}$ Department of Human Genetics, University of Utah, Salt Lake City, UT ${ }^{4}$ Virginia Commonwealth University, Department of Neurology, Richmond, VA

Correspondence:

Russell Butterfield Eccles Institute of Human Genetics, Room 2260A 15 N 2030 E Salt Lake City, UT 84112

Phone: 801-587-9887

Email: russell.butterfield@hsc.utah.edu

Grants/Funding: Myotonic Dystrophy Foundation, NIH: K08 NS097631 (RJB), R21 NS100040 (RBW), K23NS091511 (NEJ) 


\section{ABSTRACT}

Background: Myotonic dystrophy type 1 (DM1) is caused by CTG repeat expansions in the DMPK gene and is the most common form of muscular dystrophy. Patients can have long delays from onset to diagnosis, since clinical signs and symptoms are often nonspecific and overlapping with other disorders. Clinical genetic testing by Southern blot or triplet-primed PCR (TP-PCR) is technically challenging and cost prohibitive for population surveys.

Methods: Here, we present a high throughput, low-cost screening tool for CTG repeat expansions using TP-PCR followed by high resolution melt curve analysis with saturating concentrations of SYBR GreenER dye.

Results: We determined that multimodal melt profiles from the TP-PCR assay are a proxy for amplicon length stoichiometry. In a screen of 10,097 newborn blood spots, melt profile analysis accurately reflected the tri-modal distribution of common alleles from 5 to 35 CTG repeats, and identified the premutation and full expansion alleles.

Conclusion: We demonstrate that robust detection of expanded CTG repeats in a single tube can be achieved from samples derived from specimens with minimal template DNA such as dried blood spots (DBS). This technique is readily adaptable to large-scale testing programs such as population studies and newborn screening programs.

KEYWORDS: myotonic dystrophy, DMPK gene, melt curve analysis, triplet-repeat expansion, population screening 
medRxiv preprint doi: https://doi.org/10.1101/2021.01.11.21249609; this version posted January 13, 2021. The copyright holder for this preprint (which was not certified by peer review) is the author/funder, who has granted medRxiv a license to display the preprint in perpetuity.

\section{1] INTRODUCTION}

Myotonic dystrophy type 1 (DM1) is an autosomal dominant disorder characterized by early onset cataracts, myotonia, muscle weakness, cardiac arrhythmias, respiratory failure, and gastrointestinal dysfunction. ${ }^{1}$ DM1 is caused by an expansion of the trinucleotide CTG repeat in the 3' non-coding region of the DMPK gene (OMIM \#605377) on chromosome 19q13.3.2-4 Expansions of $\geq 50$ CTG repeats are considered pathogenic, while expansions of 35-49 CTG repeats result in a premutation state at risk for passing expanded alleles to the next generation. The mutational reservoir for most expanded alleles is an ancient linkage disequilibrium block with 18-35 CTG repeat alleles that varies in haplotype frequency between human populations. ${ }^{5}$

DM1 is the most common form of muscular dystrophy with prevalence estimates between 0.5 and 1.5 per $10,000 .^{6-8}$ Diagnosis is based on clinical signs and symptoms that are often non-specific and overlapping with other disorders, followed by genetic testing to detect the CTG repeat expansion in DMPK. Given the complexity of diagnosis and variability of clinical symptoms, diagnostic delays of 7 years or more from onset of symptoms are common. ${ }^{9}$ Diagnosis in muscular dystrophies, even in very rare forms of muscular dystrophy has been simplified by the proliferation of next-generation sequencing panels and exome sequencing, however, triplet repeat disorders such as DM1 are not routinely identified by these sequencing methods, and many patients with DM1 continue to have long diagnostic delays.

The gold standard for clinical genetic testing for DM1 uses a Southern blot technique to estimate the size of the CTG expansion. ${ }^{10}$ There are a number of challenges with this technique, including the requirement for a large amount of DNA and the amount of time required to perform the method. More recently, fluorescently labeled triplet-primed PCR (TP-PCR) and fragment sizing by capillary electrophoresis has been proposed as an alternative for diagnosis of DM1 ${ }^{11,12}$ and for other triplet repeat expansion disorders such as Fragile $X$ syndrome and Huntington disease ${ }^{13,14}$. The TP-PCR methodology uses a $(C T G)_{n}$ or $(C A G)_{n}$ repeat primer to generate a nested set of fragments from the expanded allele, and the observed 'ladder' of amplicons is detected by capillary electrophoresis. Both Southern blot and TP-PCR with capillary electrophoresis are technically challenging and limited by cost and difficulty of performing the assay on a large 
medRxiv preprint doi: https://doi.org/10.1101/2021.01.11.21249609; this version posted January 13, 2021. The copyright holder for this preprint (which was not certified by peer review) is the author/funder, who has granted medRxiv a license to display the preprint in perpetuity.

scale, such as in a population screen. A simplified approach using TP-PCR combined with a melt curve analysis (MCA) has been developed for detection of repeat expansions in several triplet repeat disorders including DM1, Fragile $X$ syndrome, and Huntington disease. ${ }^{15-17}$ This TP-PCR with MCA approach in DM1 is based on nonsaturating SYBR Green I intercalating dye to detect expansion of the $(\mathrm{CTG})_{\mathrm{n}}$ repeat in $D M P K{ }^{16}$ In this technique, a slow temperature ramp allows the limiting SYBR Green I dye to re-equilibrate to longer duplexes, thus suppressing the melt detection of shorter, lower $T_{\mathrm{m}}$ amplicons while maintaining the ability to detect decreased fluorescence from the melting of larger, higher $T_{\mathrm{m}}$ amplicons. Under conditions optimized for the balance between dye and amplicon concentration, this technique preferentially detects higher length products in the nested set of TP-PCR fragments, reducing a multimodal melt curve to a unimodal profile. The requirement for balancing the limiting dye concentration versus the concentration of the longer TP-PCR fragments may be challenging for crude DNA inputs lower than 5 ng, such as might be obtained from a dried blood spot (DBS) sample commonly used in population screens.

Saturating intercalating dyes such as SYBR GreenER, EvaGreen, and LCGreen have been developed for high-resolution melting analysis of multimodal melt curves. These dyes are less inhibitory to PCR and can be used at a higher concentration to reduce the level of dye relocation during melting. Here, we demonstrate that by using SYBR GreenER dye during TP-PCR with MCA, we can achieve accurate detection of expanded CTG repeats from DBS samples using the full multimodal melt profiles from the nested set of amplicons. This technique uses a simplified DNA extraction from a 3mm DBS sample and provides a rapid, inexpensive test for expansion of the $(C T G)_{n}$ repeat in the DMPK gene that is readily adaptable to large-scale screening programs such as population studies and newborn screening programs.

\section{2 | METHODS}

\subsection{Ethical Compliance}

The study was performed under University of Utah Institutional Review Board approved protocols (IRB \#40092 and IRB \#87466). 
medRxiv preprint doi: https://doi.org/10.1101/2021.01.11.21249609; this version posted January 13, 2021. The copyright holder for this preprint (which was not certified by peer review) is the author/funder, who has granted medRxiv a license to display the preprint in perpetuity.

It is made available under a CC-BY-ND 4.0 International license .

\section{$\underline{2.2}$ Study Samples}

Genomic DNA for control samples was purified from whole blood from individuals with a clinical diagnosis of DM1 and from unaffected controls after providing written informed consent. Control samples included fully expanded, clinically affected subjects with DM1 ( $\geq 50$ CTG repeats), subjects with premutation at high risk for passing expanded repeats in progeny (35-49 CTG repeats), subjects with intermediate expansions of the CTG repeat but still in the normal range (18-34 CTG repeats), and normal subjects with 5-17 CTG repeats. Genomic DNA for the haplotype analysis was derived from non-DM1 individuals with high density single nucleotide polymorphism (SNP) genotypes to identify inheritance of the three common DMPK haplotypes. ${ }^{5}$

Population based test samples were derived from 10,224 consecutive anonymous newborn DBS from the Newborn Screening Program at the New York State Newborn Screening Program, Wadsworth Center, New York State Department of Health. The DBS did not include samples known to be repeats from newborns already sampled, those whose parents requested that specimens not be used for research, those that were unsuitable for screening/DNA analysis, and specimens for which there wasn't enough blood left for research. Three-millimeter punches were individually placed into 96-well non-skirted polypropylene PCR plates with each plate containing nine consecutive blank spaces for control samples. The control row was rotated from row $\mathrm{A}$ to $\mathrm{H}$ and after shipment to Utah, plates were stored at $4{ }^{\circ} \mathrm{C}$ until DNA purification was performed.

\subsection{DNA Purification From Dried Blood Spots}

We modified the low-cost CASM method developed at the New York State Dept. of Health to extract DNA from DBS ${ }^{18}$. Four 96 -well plates were processed in batches beginning with the addition of $150 \mu$ per well of Red Blood Cell (RBC) lysis solution (10 $\mathrm{mM}$ Tris- $\mathrm{HCl}, 320 \mathrm{mM}$ Sucrose, $2.4 \mathrm{mM} \mathrm{MgCl} 2,1 \%$ Triton X-100, $\mathrm{pH}$ 8.0). The plates were covered with clear acetate plate sealers, briefly centrifuged and shaken for 20 min at $750 \mathrm{rpm}$ on a Heidolph Titramax 1000 plate shaker. Subsequent reagent additions were done with a Velocity11 VPrep 96-channel pipetting station and liquid removal was done manually with 12-channel pipettors. After removal of the RBC lysis solution, the DBS were washed twice with $160 \mu \mathrm{l}$ of $\mathrm{dH}_{2} \mathrm{O}$ and shaken for 30 min. After this, $50 \mu \mathrm{l}$ of 
medRxiv preprint doi: https://doi.org/10.1101/2021.01.11.21249609; this version posted January 13, 2021. The copyright holder for this preprint (which was not certified by peer review) is the author/funder, who has granted medRxiv a license to display the preprint in perpetuity.

It is made available under a CC-BY-ND 4.0 International license .

$100 \mathrm{mM} \mathrm{NaOH}, 2 \%$ Tween 20 was added per well, the plates were sealed and heated to $95{ }^{\circ} \mathrm{C}$ for $12 \mathrm{~min}$. After briefly centrifuging the plates, $50 \mu \mathrm{l}$ of $100 \mathrm{mM}$ Tris- $\mathrm{HCl}, 2 \mathrm{mM}$ EDTA, pH 8.0 was added per well, the plates were shaken for $10 \mathrm{~min}$, briefly centrifuged and the lysate containing genomic DNA was transferred to a fresh 96-well plate $(0.2 \mathrm{ml}$ non-skirted Thermo Scientific PCR plate), covered with foil sealers and stored at $4^{\circ} \mathrm{C}$. The concentration of genomic DNA isolated from 939 DBS was estimated from real-time PCR comparing cycle threshold $(\mathrm{Ct})$ values to known concentrations using a linear model with a median of $1.11 \mathrm{ng} / \mu \mathrm{l}$ (lower quartile $0.15 \mathrm{ng} / \mu \mathrm{l}$ and upper quartile $6.44 \mathrm{ng} / \mu \mathrm{l}$ ).

\subsection{Triplet Primed PCR (TP-PCR) and Melt Curve Analysis (MCA)}

TP-PCR for both 5' and 3' ends of the (CTG)n repeat in DMPK (NM_004409.5) were adapted from conditions published by Falk et al. ${ }^{19}$ and optimized for use of SYBR® GreenER $^{\mathrm{TM}}$ dye to facilitate MCA (Figure 1A). For the 5' TP-PCR, amplification was performed in 384-well PCR plates with $10 \mu \mathrm{l}$ reaction volumes consisting of $1 \mu \mathrm{l}(\sim 1 \mathrm{ng})$ genomic DNA and the following $9 \mu \mathrm{l}$ reagent master mix: $0.5 \mu \mathrm{M} D M P K$ forward primer (5'-GGGGCTCGAAGGGTCCTTGT-3'), $0.05 \mu \mathrm{M} \quad(\mathrm{CAG})_{6}$ reverse primer (5'AGCGGATAACAATTTCACACAGGACAGCAGCAGCAGCAGCAG-3'), $0.5 \mu \mathrm{M}$ tail primer (5'-AGCGGATAACAATTTCACACAGGA-3'), 0.5 M GC-RICH Resolution Solution (Roche), and 1X SYBR Select Master Mix (Thermo Fisher Scientific, cat. \# 4472913, contains SYBR GreenER dye, AmpliTaq DNA Polymerase UP, dNTPs with dUTP/dTTP, heat-labile UDG, ROX passive reference dye and buffer components). For 3' TP-PCR, amplification was performed using the same procedure but substituting $0.5 \mu \mathrm{M} D M P K$ reverse primer (5'-GTGCGTGGAGGATGGAAC-3'), $0.05 \mu \mathrm{M}$ (CTG)6-forward primer (5'AGCGGATAACAATTTCACACAGGATGCTGCTGCTGCTGCTGCTG-3'), and $0.5 \mu \mathrm{M}$ tail primer (5'-AGCGGATAACAATTTCACACAGGA-3'). Thermocycling was performed on either a MJ Research PTC-225 or an Applied Biosystems Veriti 384-well Thermal Cycler with the following cycling parameters: UDG activation of $50{ }^{\circ} \mathrm{C}$ for $2 \mathrm{~min}$ followed by AmpliTaq activation at $95{ }^{\circ} \mathrm{C}$ for $1 \mathrm{~min}$, followed by 50 cycles of denaturation at $95{ }^{\circ} \mathrm{C}$ for $1 \mathrm{~min}$, annealing at $60^{\circ} \mathrm{C}$ for $1 \mathrm{~min}$, and extension at $72^{\circ} \mathrm{C}$ for $3 \mathrm{~min}$. A $72{ }^{\circ} \mathrm{C}$ final extension for 10 min followed by a $4{ }^{\circ} \mathrm{C}$ hold completed the reaction; plates were stored at $-20{ }^{\circ} \mathrm{C}$. After PCR cycling and storage, samples underwent high resolution MCA on an Applied 
medRxiv preprint doi: https://doi.org/10.1101/2021.01.11.21249609; this version posted January 13, 2021. The copyright holder for this preprint (which was not certified by peer review) is the author/funder, who has granted medRxiv a license to display the preprint in perpetuity.

It is made available under a CC-BY-ND 4.0 International license .

Biosystems QuantStudio $12 \mathrm{~K}$ Flex instrument with a single cycle of $98{ }^{\circ} \mathrm{C}$ for 15 seconds, $60{ }^{\circ} \mathrm{C}$ for 15 seconds, and final ramp to $98{ }^{\circ} \mathrm{C}$ at $0.05{ }^{\circ} \mathrm{C} / \mathrm{s}$. Temperature, normalized fluorescence intensity $(\mathrm{Rn})$ and the negative derivative of $\mathrm{Rn}$ with respect to temperature (-dF/dT) were exported using the QuantStudio 12K Flex software. For screens using DBS samples, two sets of the nine TP-PCR amplification and MCA controls were included in each 384-well plate. The nine control samples, with CTG repeat size is denoted as allele1::allele 2 , included four in the normal/intermediate range $(5:: 5,5:: 13,5:: 14$, and $14:: 30)$, one in the premutation range $(12:: 37)$, and four in the fully expanded range (5::75, $5:: 80,5:: 480$, and $14:: 2530)$.

\subsection{Primer Extension and Melt Curve Reconstruction}

Primer extension reactions on post-PCR amplicons were used to reconstruct predicted melt curve profiles. PCR primers and nucleotides were removed after TP-PCR amplification with ExoSAP-IT (Thermo Fisher Scientific) and $10 \mu$ primer extension reactions were composed of: $10 \mathrm{mM}$ Tris- $\mathrm{HCl}, \mathrm{pH} 8.3,50 \mathrm{mM} \mathrm{KCl}, 1.5 \mathrm{mM} \mathrm{MgCl}_{2}, 0.2$ mM dNTPs, $0.05 \mu$ l Platinum Taq DNA polymerase with $0.36 \mu$ of KB Extender (Thermo Fisher Scientific), 2 pM of 5' 6-FAM-labeled DMPK forward primer, and $2 \mu$ of ExoSAPIT treated post-PCR amplicons. Thermocycling conditions included an initial denaturation at $95^{\circ} \mathrm{C}$ for $5 \mathrm{~min}$., followed by 10 cycles of $95^{\circ} \mathrm{C}$ for $15 \mathrm{sec}, 55^{\circ} \mathrm{C}$ for $15 \mathrm{sec}, 68^{\circ} \mathrm{C}$ for $30 \mathrm{sec}$ and a final extension at $68^{\circ} \mathrm{C}$ for $7 \mathrm{~min}$. $3 \mu \mathrm{l}$ of the primer extension reactions were added to $10 \mu \mathrm{l}$ of Hi-Di Formamide containing $0.5 \mu \mathrm{l}$ of GeneScan 500 LIZ dye size standard and fragment analysis was performed on an ABI3730 capillary electrophoresis instrument. Electropherograms were processed using $\mathrm{R}$ library functions in the seqinr package to assign fragment sizes and peak heights. ${ }^{20}$ The melt curve reconstruction used a series of TP-PCR fragment sequences beginning with 5'GGGGCTCGAAGGGTCCTTGTAGCCGGGAATG(CTG)„AAATTGTTATCCGCT-3’, where $\mathrm{n}$ ranged from 5 to 88 CTG repeats. The prediction of - $d$ (Helicity)/d(Temp) for each fragment size was modeled by the uMelt Batch software using the default (SantaLucia) thermodynamic library with parameters adjusted to: $\left[\mathrm{Mono}^{+}\right]=22 \mathrm{mM}$, free $\left[\mathrm{Mg}^{++}\right]=1.7$ $\mathrm{mM}$, and $\mathrm{DMSO}=8 \% .{ }^{21}$ Predictions were in the temperature range of $60-98^{\circ} \mathrm{C}$ at $0.1^{\circ} \mathrm{C}$ 
medRxiv preprint doi: https://doi.org/10.1101/2021.01.11.21249609; this version posted January 13, 2021. The copyright holder for this preprint (which was not certified by peer review) is the author/funder, who has granted medRxiv a license to display the preprint in perpetuity.

It is made available under a CC-BY-ND 4.0 International license .

resolution and the fragment size ratios seen by primer extension were used to generate a composite melt curve.

\subsection{CTG Repeat Size Confirmation by Fragment Analysis}

Genomic DNA selected for direct sizing analysis was further purified using Zymo DNA Clean and Concentrator-5 columns (Zymo Research, Irvine, CA) in order concentrate the sample for optimal use in follow-up assays. Fifty $\mu$ of DNA derived from the DBS was purified according to the manufacturer's specifications and samples were eluted in $25 \mu \mathrm{l}$. Direct PCR amplification of the $(\mathrm{CTG})_{\mathrm{n}}$ repeat from $2 \mu \mathrm{l}$ of Zymo purified DNA was performed in $25 \mu \mathrm{l}$ reactions composed of: $10 \mathrm{mM}$ Tris- $\mathrm{HCl}, \mathrm{pH} 8.3,50 \mathrm{mM} \mathrm{KCl}, 1.5 \mathrm{mM}$ $\mathrm{MgCl}_{2}, 0.2 \mathrm{mM}$ dNTPs, $0.75 \mu$ l of KB Extender, $0.1 \mu$ Platinum Taq DNA polymerase (Invitrogen, cat. \#10966-034), 5 pM of primers (6-FAM-labeled DMPK forward primer and DMPK reverse primer: 5'-GTGCGTGGAGGATGGAAC-3'). Thermocycler conditions included an initial denaturation at $95^{\circ} \mathrm{C}$ for 5 min followed by 33 cycles of $95{ }^{\circ} \mathrm{C}$ for 15 $\mathrm{sec}, 55^{\circ} \mathrm{C}$ for $15 \mathrm{sec}, 68^{\circ} \mathrm{C}$ for $30 \mathrm{sec}$ and a final extension at $68^{\circ} \mathrm{C}$ for $7 \mathrm{~min}$. Fragment analysis was performed on an ABI3730xl capillary instrument and electropherograms were processed as described above for primer extensions. Samples suspected to have expansions of $>75$ CTG repeats were further validated using the AmplideX PCR/CE DMPK Kit (Asuragen, Austin, TX) and PCR reactions were carried out according to the manufacturer's specifications. $2 \mu \mathrm{l}$ of the amplicons were added to $10 \mu \mathrm{l}$ of $\mathrm{Hi}-\mathrm{Di}$ formamide containing $2 \mu \mathrm{l}$ of ROX 1000 size ladder (Asuragen, Austin, TX) and electrophoresed on an ABI3730xI instrument. The electropherograms were analyzed using GeneMapper v.4.0 and repeat sizes were determined using the Asuragen Macrotable software.

\section{7 | Classification of Melt Curve Profile and Clustering}

Derivative plots of normalized $-\mathrm{dF} / \mathrm{dT}$ values for each sample were plotted from $80{ }^{\circ} \mathrm{C}$ to $94^{\circ} \mathrm{C}$ with averaged $-\mathrm{dF} / \mathrm{dT}$ melt curves from 4 positive controls with full expansion ( $\geq 50$ CTG repeats) and a vertical threshold at $90{ }^{\circ} \mathrm{C}$ as reference guides for scoring (Figure S1). Individual plots for each sample were scored in a blinded fashion by four reviewers and classified into one of six categories based on visual inspection of the melt curve 
medRxiv preprint doi: https://doi.org/10.1101/2021.01.11.21249609; this version posted January 13, 2021. The copyright holder for this preprint (which was not certified by peer review) is the author/funder, who has granted medRxiv a license to display the preprint in perpetuity.

It is made available under a CC-BY-ND 4.0 International license .

profile: normal, intermediate, premutation, expanded, uncertain, and fail. A training set of melt profiles with known CTG repeat sizes was used to establish after group review, a consensus for the criteria used to assign a melt profile to a category. Final classification for each sample was made by the majority call from the four blinded reviewers. In the case of a tie, the higher (expanded > premutation >intermediate > normal) classification was assigned. For unsupervised clustering analysis, normalized -dF/dT data interpolated to $0.05{ }^{\circ} \mathrm{C}$ increments and a temperature range of $87.25{ }^{\circ} \mathrm{C}-96.70{ }^{\circ} \mathrm{C}$ was used for clustering with the Uniform Manifold Approximation and Projection (UMAP) dimension reduction technique and visualized with the fit_transform method and parameters of min_dist $=0.6, n \_$neighbors $=200$, and $n \_$components $=3.22$

\subsection{Haplotype/Diplotype Analysis}

Surveys of the DMPK CTG repeat size on normal chromosomes from global populations have shown a trimodal distribution of $(C T G)_{5},(C T G)_{8-17},(C T G)_{18-35}$ repeat size ranges. These allelic bins correspond to three common haplotypes containing the DMPK CTG repeat within a strong block of linkage disequilibrium (LD), with most pathogenic CTG repeat expansions occurring on the (CTG) $18-35$ repeat haplotype. ${ }^{5}$ These haplotypes were defined by genotyping biallelic markers spanning a distance of $21 \mathrm{~kb}$ that included a 1-kb deletion of an Alu element, a Hinfl restriction site and a TaqI restriction site polymorphism. We SNP tagged this haplotype block by using three single nucleotide polymorphisms (SNPs) including the originally described Hinfl (rs16939) and Taql polymorphisms (rs10415988) and a SNP (rs4802275) in complete LD with the Alu structural variant. We used genomewide single nucleotide polymorphism (SNP) genotypes from non-DM1 control samples to identify individuals homozygous for the three common SNP tagged DMPK region haplotypes, with (---) designating the $\mathrm{CTG}_{18-35}$ haplotype, (+++) designating the $\mathrm{CTG}_{8-17}$ haplotype, and (-+-) designating the $\mathrm{CTG}_{5}$ haplotype, with their reference/alternate alleles indicated by $(-/+)$ symbols. Genotype imputation and phasing for these samples has been previously described ${ }^{23}$ and haplotype clustering was performed using the Haplostrips tool. ${ }^{24}$ TP-PCR with MCA and fragment analysis was performed on 45 non-DM1 samples 
medRxiv preprint doi: https://doi.org/10.1101/2021.01.11.21249609; this version posted January 13, 2021. The copyright holder for this preprint (which was not certified by peer review) is the author/funder, who has granted medRxiv a license to display the preprint in perpetuity.

homozygous for each of the three common DMPK haplotypes to confirm the CTG repeat sizes.

\section{3 | RESULTS}

Our three primer TP-PCR design amplifies a minimally sized $73 \mathrm{bp}$ fragment from the 5 ' end of the common $\operatorname{DMPK}(\mathrm{CTG})_{5}$ allele (Figure 1A) and $160 \mathrm{bp}$ fragment from the 3' TP-PCR. To demonstrate that MCA with saturating intercalating dye can discriminate CTG repeat size classes, we compared melt profiles from TP-PCR from both 5' and 3' ends of the DMPK $(\mathrm{CTG})_{\mathrm{n}}$ repeat. Unimodal melting behavior was observed for the smallest CTG repeat control (5::5 homozygotes), while for heterozygous control samples with a range of normal, intermediate, premutation, and fully expanded CTG repeats, the melting behavior shifted from unimodal to multimodal melt curves as the repeat length increased (Figure 1B). The 5' and 3' TP-PCR were comparable across a wide spectrum of CTG repeat sizes although the smaller 5' TP-PCR amplicon enhanced resolution at lower temperatures; therefore, subsequent analyses included only the 5' TP-PCR. To compare the melt profile using our protocol to a predicted melt profile based on the observed sizes and ratios of TP-PCR amplicons, we used primer extension reactions after TP-PCR to determine the actual fragment sizes and stoichiometries produced by these conditions from heterozygous samples with a normal CTG repeat $(5:: 13)$ versus an expanded CTG repeat (5::480) (Figure 2A). We used thermodynamic calculations for the individual primer extension products to predict a curve $(-\mathrm{dH} / \mathrm{dT})$ for the negative derivative of helicity versus temperature ${ }^{21}$ based on the fragment size of the primer extension peaks. We then weighted each individual curve by their peak heights observed in the primer extension and calculated a composite melt curve by summing these weighted curves (Figure 2B). The predicted $-\mathrm{dH} / \mathrm{dT}$ curve was a fair approximation of the actual $-\mathrm{dF} / \mathrm{dT}$ melt curve (Figure $2 \mathrm{C}$ ), confirming that the shape of the $-\mathrm{dF} / \mathrm{dT}$ melt curve between $83^{\circ} \mathrm{C}$ and $95^{\circ} \mathrm{C}$ is a composite of the underlying melting behavior of the TP-PCR fragment ladders and contains useful information about the CTG repeat size. 
medRxiv preprint doi: https://doi.org/10.1101/2021.01.11.21249609; this version posted January 13, 2021. The copyright holder for this preprint (which was not certified by peer review) is the author/funder, who has granted medRxiv a license to display the preprint in perpetuity.

It is made available under a CC-BY-ND 4.0 International license .

Melt profiles for nine control samples with a broad range of CTG repeat sizes were then analyzed, including four in the normal/intermediate range $(5:: 5,5:: 13,5:: 14$, and $14:: 30)$, one in the premutation range $(12:: 37)$, and four in the fully expanded range $(5:: 75$, $5:: 80,5:: 480$, and $14:: 2530)$. Samples with larger CTG repeat sizes had more area under the $-\mathrm{dF} / \mathrm{dT}$ melt curve at higher temperature than those with normal or smaller repeat sizes, and their melt profiles paralleled their predicted curves from primer extension analysis (Figure 3A). To determine the optimal amount of template DNA, we performed our TP-PCR assay using a serial dilution of genomic DNA from $20 \mathrm{ng}$ to $0.02 \mathrm{ng}$, representing a range of $\sim 6000$ to 6 genome copy equivalents per reaction. Our results indicated that the TP-PCR assay and MCA were robust across a broad range of DNA concentrations, with successful amplification in as low as 0.02 ng genomic DNA (Figure 3B). Ultimately, we used $\sim 2$ ng template for all other analyses.

To better understand the behavior of the melt profile on control samples from the normal population, we chose 45 individuals who were homozygous for each of the three common DMPK haplotype groups for further analysis (Figure 4A). We sized the CTG repeats from these 45 individuals and observed a similar trimodal distribution of repeat sizes that recapitulated the original association of $\mathrm{CTG}_{5}, \mathrm{CTG}_{8-17}$, and $\mathrm{CTG}_{18-35}$ size ranges associated with the Alul/Hinfl/Taql haplotypes in worldwide populations ${ }^{5,23}$. The $(-+-) /(-+-)$ diplotype had exclusively $\mathrm{CTG}_{5}$ repeats, the $(+++) /(+++)$ diplotype had repeat sizes in the $\mathrm{CTG}_{8-14}$ range, and the $(---) /(---)$ diplotype had repeat sizes in the $\mathrm{CTG}_{14-40}$ range (Figure 4B). We screened these 45 homozygous DMPK diplotype samples and 57 individuals with clinical features of DM1 using the TP-PCR assay with MCA and observed unimodal melt profiles from the $(-+-) /(-+-)$ and $(+++) /(+++)$ diplotype groups, and multimodal melt profiles from the

$(---) /(---)$ diplotype and clinically affected DM1 subjects (Figure 4C). Individual melt profiles for each sample were scored by blinded reviewers as normal (unimodal below 90 ${ }^{\circ} \mathrm{C}$ ), intermediate (bimodal below $90^{\circ} \mathrm{C}$ ), premutation (bimodal crossing $90{ }^{\circ} \mathrm{C}$ ), or expanded (multimodal above $90^{\circ} \mathrm{C}$ ) and a classification was made based on the consensus of the blinded calls as detailed in Methods. All 57 DM1 subjects were classified as expanded by blinded review, while all the $\left(-_{+-}\right) /\left(-^{+-}\right)$and $(+++) /(+++)$ 
medRxiv preprint doi: https://doi.org/10.1101/2021.01.11.21249609; this version posted January 13, 2021. The copyright holder for this preprint (which was not certified by peer review) is the author/funder, who has granted medRxiv a license to display the preprint in perpetuity.

It is made available under a CC-BY-ND 4.0 International license .

diplotype samples were classified as normal (Table 1). The $15(---) /(---)$ diplotype samples showed more variation, with blinded scores in three out of the four classes. The two samples that scored as normal had the smallest sizes (14 and 17 repeats), the nine samples scored as intermediate had intermediate sizes (21 to 28 repeats) and the four samples scored as premutation had the largest sizes (29 to 40 repeats) (Supplemental Table 1).

To demonstrate use of this assay on a larger scale, applicable to population level studies, we performed our 5' TP-PCR assay on 10,224 de-identified samples derived from DBS along with 522 control samples (58 replicates of 9 samples with known repeat sizes). Melt profiles of controls and DBS samples were reviewed by 4 blinded reviewers and scored as normal, intermediate, premutation, expanded, uncertain, or failed based on visual assessment of the melt as described above. Replicate control samples were scored by blinded reviewers and in most cases were classified correctly based on the known allele size (Table 2). Positive controls, with CTG repeats $\geq 50$, were classified as expanded in all cases. The one premutation control, with 37 CTG repeats, was classified as premutation in 57 of 58 replicates. The control sample in the intermediate range (30 CTG repeats) showed more variability in the blinded scoring. In this case, 34 (58.6\%) were scored as intermediate, $23(39.6 \%)$ as premutation, and 1 (1.7\%) as expanded. For the three control samples in the normal range (5-14 CTG repeats), $93-96 \%$ of these replicates were scored as normal.

For the 10,224 DBS samples, we obtained a successful melt profile in 10,097 (98.76\%) (Table 2). From these 8,416 (82.3\%) were scored by blinded reviewers as normal and 1,547 (15.1\%) as intermediate, in good agreement with observed frequencies of the $\mathrm{CTG}_{5}$ and $\mathrm{CTG}_{8-17}$ versus the $\mathrm{CTG}_{18-35}$ haplotypes in non-African populations ${ }^{5}$. We determined CTG repeat sizes from 142 intermediate samples and observed that 121 $(85 \%)$ had a repeat size between 18 and 30 (median size $=\mathrm{CTG}_{24}$ ) for the larger allele, indicating that the intermediate class was enriched for the $\mathrm{CTG}_{18-35}(---)$ haplotype. The remaining 21 samples were in the normal range with size $<18$ repeats. For an unbiased evaluation of the melt curve profiles based on the full set of 10,097 samples, we used the $-\mathrm{dF} / \mathrm{dT}$ melt curves in a clustering analysis to construct a UMAP visualization. The 
clustering analysis demonstrated proximity and clustering of similar size repeats (Figure 5A).

The blinded review of 10,097 DBS samples resulted in 16 samples $(0.16 \%)$ classified as expanded (Figure 5B, Supplemental Figure 2) and 79 as premutation $(0.78 \%)$ (Supplemental Figure 3). All samples classified as expanded or premutation by blinded review were referred for direct sizing performed by fluorescent PCR across the CTG repeat or using the Amplidex DM1 Dx Kit. Six of the 16 samples identified by screening were found to have CTG repeats $\geq 50$, with expanded allele sizes of 51,62 , $102,148,149$, and $>200$ CTG repeats (Figure 6). Six of the samples that screened as false positive had allele sizes in the intermediate range $(22:: 24,5:: 22,11:: 22,12:: 22$, $12:: 17,12:: 17)$ and four had allele sizes in the normal range $(13:: 15,5:: 13,13:: 13,5:: 5)$. For the 79 samples that were classified as premutation by blinded reviewers, 16 were found to have true CTG expansions in the premutation range with allele sizes from 3549, 26 were found to have CTG repeat alleles in the intermediate range, and 37 with CTG repeat alleles in the normal range (Supplemental Figure 3). None had full expansion of the CTG repeat $(\geq 50)$. 
medRxiv preprint doi: https://doi.org/10.1101/2021.01.11.21249609; this version posted January 13, 2021. The copyright holder for this preprint (which was not certified by peer review) is the author/funder, who has granted medRxiv a license to display the preprint in perpetuity.

It is made available under a CC-BY-ND 4.0 International license.

\section{4 | DISCUSSION}

Here we present a low-cost, high throughput assay for identifying expanded CTG repeats in the DMPK gene in a single tube using TP-PCR with MCA with the saturating dye SYBR GreenER. This assay relies on identifying a shift in melting profile in samples with expanded CTG repeats that is readily identified by visual examination of the melt profile. Using this assay, we were able to correctly detect expansions $\geq 50$ CTG repeats with $100 \%$ sensitivity (232 of 232 control samples classified as expanded) and $99 \%$ specificity (287 of 290 control samples classified not expanded). In addition, our assay is able to detect shifts in the melt profile from samples with CTG repeats in the premutation (35-49 repeats) and intermediate (18-34 repeats) ranges but with less sensitivity/specificity. Our ability to identify samples with the putative (CTG) $18-35$ risk haplotype as intermediate melt profiles observed in $15 \%$ of our samples confirms results from earlier DMPK haplotype analysis in worldwide populations and indicates the utility of using a full spectrum of fragment lengths in the melt analysis.

Our assay is robust for use with 1-2 ng template DNA from a simple DNA preparation on DBS samples, enhancing scalability for large screens. While we use 1-2 ng of template DNA for our study here, our assay is successful with as low as $0.02 \mathrm{ng}$ (6 genome copy equivalents) input DNA, making the assay practical for use with samples derived from sources with limited DNA. In contrast, alternative methods using for TP-PCR with MCA for the CTG repeat in DMPK require as much as $100 \mathrm{ng}$ input DNA and lose signal below $5 \mathrm{ng}^{25}$

Our assay builds on previous methods to use MCA to detect repeat expansion alleles. Multimodal melt curves are typically observed in MCA with mixtures of PCR amplicons of different lengths or sequence, since intercalating dyes bind non-specifically to any double-stranded DNA molecules. An alternative TP-PCR/MCA method uses nonsaturating conditions with SYBR Green I dye, where the limiting dye dissociates from melting lower $T_{m}$ molecules and re-intercalates to higher $T_{m}$ double-strand molecules during a slow temperature ramp, resulting in a unimodal derivative melt peak observed only at the highest melting temperature. ${ }^{16,25}$ While this elegant assay simplifies the melt curve interpretation, it requires precise matching of dye concentration with the final concentration of PCR amplicons that may be difficult with lower quality DNA samples. 
medRxiv preprint doi: https://doi.org/10.1101/2021.01.11.21249609; this version posted January 13, 2021. The copyright holder for this preprint (which was not certified by peer review) is the author/funder, who has granted medRxiv a license to display the preprint in perpetuity.

It is made available under a CC-BY-ND 4.0 International license.

Notably, a similar TP-PCR/MCA assay has been successfully used for screening DBS samples for triplet repeat expansion in fragile $X$ syndrome, but that assay requires significantly more template DNA (a minimum of 20ng DNA vs 1-2ng DNA for our assay) from a more complex DNA purification using a column prep. ${ }^{26}$ While successful in screening, it may be difficult to scale up this process to thousands of samples. In our study, we re-evaluate the premise that non-saturating conditions in TP-PCR with MCA is superior to saturating conditions. We show that the use of MCA with the saturating SYBR GreenER dye has comparable resolution in distinguishing the relevant range of CTG repeat expansions. In our assay, we use SYBR GreenER dye for the high resolution melt rather than other dyes commonly used in high resolution melt applications. While it is likely that other saturating dyes such as (LC Green 1, LC Green +, or EvaGreen) are also suitable for this purpose, we favor the use of SYBR GreenER because is available in a commercially available master mix (SYBR Select) which adds simplicity to the reaction preparation and scalability and minimizes variability from the reagent preparation.

To demonstrate the feasibility of this assay for deployment in a large-scale population screen, we tested 10,224 DBS samples. We successfully screened 10,097 samples, with a reaction failure rate of only $1.2 \%$. Sixteen samples were identified as expanded from screening by blinded reviewers based on MCA and secondary validation steps revealed true CTG expansions $\geq 50$ in 6 of these samples. The ten false positive samples had CTG repeat sizes in the normal to intermediate range (5 to 24 CTG repeats), resulting in positive predicted value (PPV) of $37.5 \%$ based solely on the TP-PCR/MCA which compares favorably with screening protocols for other disorders such as cystic fibrosis. ${ }^{27}$ For a combined screening approach with TP-PCR/MCA followed by the more definitive test, all false positive samples were eliminated, reflecting a PPV approaching $100 \%$ for the two-step process. For 79 samples classified as premutation by MCA, 16 were found to have true CTG repeats in the premutation range (35-49 repeats) resulting in positive predicted value of $20.3 \%$ to detect premutation carriers based solely on the TP-PCR/MCA. While we are not able to determine negative predictive value since we cannot fully exclude false negative samples, we presume that the actual number of false negatives is very low based on the absence of false positive cases in our control samples (Tables 1 and 2) and the higher than expected number of true positive samples identified 
medRxiv preprint doi: https://doi.org/10.1101/2021.01.11.21249609; this version posted January 13, 2021. The copyright holder for this preprint (which was not certified by peer review) is the author/funder, who has granted medRxiv a license to display the preprint in perpetuity. It is made available under a CC-BY-ND 4.0 International license.

here (6 per 10,000) compared to published prevalence (0.5-1.5 per 10,000). ${ }^{6-8}$ Notably, in no case was a sample that screened as intermediate or premutation by blinded review of the MCA found to have an actual repeat larger than its initial classification.

While our method adds technical simplicity to the TP-PCR with MCA method since we use saturating rather than non-saturating conditions, it has several limitations. The melt profile from our assay incorporates information from a mixture of TP-PCR products of different lengths from different alleles so the melt profile can have some heterogeneity. Interpretation of the melt profile by visual inspection can be subjective and depends somewhat on the skill experience of the reviewer. While our study was focused on assay development and included primarily visual scoring of the melt profile, our clustering analysis suggests that automated classification of melt profiles is feasible for screening of larger populations (Figure 5). While we can identify samples with suspected expanded CTG repeats $\geq 50$, and repeats in the premutation and intermediate range, we cannot determine the exact size of the repeat without follow-up testing by direct PCR or fluorescent TP-PCR, with a limit of resolution of $\sim 200$ repeats by capillary electrophoresis. For large-scale screening purposes, our assay is highly sensitive, but does result in some false positive results (10 false positive samples in 10,224 samples tested) which require follow-up testing for confirmation, however, the TP-PCR/MCA vastly narrows the search and limits the number of samples that require this type of validation. For false positive samples, we suspect that the initial TP-PCR/MCA assays may have had non-specific PCR amplicons that contributed to the melt profile. This suggests that the specificity of the initial TP-PCR primer design and PCR conditions are an important aspect for developing a robust assay.

An emerging limitation to the wider application of this technique is the competing method of repeat expansion profiling using next generation sequencing. Recent application of whole genome sequencing using short Illumina reads (100 - 150 bases) detected 15 DMPK expansions in 12,632 genomes. That study included several DM1 families that may have contributed to the higher number of detected expansions but is methodologically a powerful alternative to TP-PCR MCA assays ${ }^{28}$. Still, at an estimated cost of $\$ 0.89$ per sample for a screen that can be done in a single tube, our method is less costly and complex than next-generation sequencing strategies. 
medRxiv preprint doi: https://doi.org/10.1101/2021.01.11.21249609; this version posted January 13, 2021. The copyright holder for this preprint (which was not certified by peer review) is the author/funder, who has granted medRxiv a license to display the preprint in perpetuity.

It is made available under a CC-BY-ND 4.0 International license .

While we have optimized our TP-PCR with MCA from both 5' and 3' ends of the $(\mathrm{CTG})_{\mathrm{n}}$ expansion in DMPK, we tested only the $5^{\prime}$ assay in the larger cohort of DBS samples. Past recommendations to include both 5' and 3' TP-PCR stem from the possibility that expanded samples may be missed in TP-PCR reactions due to interruptions of the CTG repeat. ${ }^{11,16,29,30}$ However, bidirectional assays are likely unnecessary, particularly in the setting of a screening test as we have proposed here. With traditional TP-PCR careful examination of the electropherograms from published reports of DM1 cases with interrupted CTG repeats show that the TP-PCR reaction does not fail, but proceeds with interruptions to the typical sawtooth pattern seen from uninterrupted CTG repeats. ${ }^{11}$, 29, 31, 32 Indeed, TP-PCR has been used in search of interrupted repeats. ${ }^{33}$ As we have shown by melt curve reconstruction, since our application of MCA uses the full spectrum of TP-PCR products, it is robust at detecting differences in the relative proportion of fragment lengths. Furthermore, interruptions in the CTG repeat in DMPK are rare (3-5\% of cases) and almost always occur in the 3' end of the CTG repeat and would be least disruptive to the pattern of TP-PCR amplicons in our assay. $29,31,34$

DM1 is one of the most prevalent muscular dystrophies and diagnostic delays as long as seven years are common. ${ }^{9}$ Next-generation sequencing panels are increasingly used as the first diagnostic test for patients with suspected neuromuscular disorders, ${ }^{35}$ but will miss disorders due to triplet-repeat expansions such as DM1. Our assay can easily be incorporated into diagnostic panels greatly facilitating early diagnosis and avoiding additional unnecessary testing. The low cost and simplicity of this assay make it an ideal tool for screening programs interested in identifying both patients with DM1 and also patients with premutation alleles at risk for passing expanded CTG repeat alleles to children. Further, this technique can be easily adapted to population screens for other disorders caused by repeat expansions such as type 2 myotonic dystrophy, Huntington disease, Fragile $\mathrm{X}$ syndrome, and others. 
ACKNOWLEDGEMENTS: We are grateful to the Myotonic Dystrophy Foundation for funding for this study. Additional funding from K08 NS097631 (RJB), R21 NS100040 (RBW), K23NS091511 (NEJ). We are grateful to Kaycie Lawson, MS, Mark Shook, BS, Zoe Edmunds, BS, Denise Kay, PhD and Michele Caggana, ScD, FACMG of the New York State Newborn Screening Program, Wadsworth Center, New York State Department of Health for providing deidentified samples, and to Michael Klein, BS of the University of Utah Genomics Core for providing instrumentation and expertise for acquiring melt curves.

Data Availability Statement: The data that support the findings of this study are available from the corresponding author upon reasonable request.

Conflicts of Interest Statement: RJB is receiving funding via contracts for clinical trials from PTC Therapeutics, Sarepta Therapeutics, Pfizer, Biogen, Carpricor, and Catabasis. He serves on scientific advisory boards for Sarepta Therapeutics, Biogen, and Pfizer. NEJ has received grant funding from NINDS (R21TR003184; R01NS104010), CDC (U01DD001242) and the FDA (7R01FD006071). He receives royalties from the CCMDHI and the CMTHI. He receives research funds from Dyne, AveXis, CSL Behring, Vertex Pharmaceuticals, Fulcrum Therapeutics, ML Bio, Sarepta, and Acceleron Pharma. He has provided consultation for AveXis, AMO Pharma, Strongbridge BioPharma, Acceleron Pharma, Fulcrum Therapeutics, Dyne, ML Bio, Avidity, and Vertex Pharmaceuticals. Cl, $\mathrm{KM}, \mathrm{TN}, \mathrm{DMD}, \mathrm{BD}, \mathrm{MKF}$ and RBW report no conflicts of interest. 
medRxiv preprint doi: https://doi.org/10.1101/2021.01.11.21249609; this version posted January 13, 2021. The copyright holder for this preprint (which was not certified by peer review) is the author/funder, who has granted medRxiv a license to display the preprint in perpetuity.

It is made available under a CC-BY-ND 4.0 International license .

\section{REFERENCES}

1. Turner C, Hilton-Jones D. Myotonic dystrophy: diagnosis, management and new therapies. Curr Opin Neurol 2014;27:599-606.

2. Mahadevan M, Tsilfidis C, Sabourin L, et al. Myotonic dystrophy mutation: an unstable CTG repeat in the 3' untranslated region of the gene. Science 1992;255:1253-1255.

3. Fu YH, Pizzuti A, Fenwick RG, Jr., et al. An unstable triplet repeat in a gene related to myotonic muscular dystrophy. Science 1992;255:1256-1258.

4. Brook JD, McCurrach ME, Harley HG, et al. Molecular basis of myotonic dystrophy: expansion of a trinucleotide (CTG) repeat at the 3 ' end of a transcript encoding a protein kinase family member. Cell 1992;68:799-808.

5. Tishkoff SA, Goldman A, Calafell F, et al. A global haplotype analysis of the myotonic dystrophy locus: implications for the evolution of modern humans and for the origin of myotonic dystrophy mutations. Am J Hum Genet 1998;62:1389-1402.

6. Do TN, Street N, Donnelly J, et al. Muscular Dystrophy Surveillance, Tracking, and Research Network pilot: Population-based surveillance of major muscular dystrophies at four U.S. sites, 20072011. Birth Defects Res 2018;110:1404-1411.

7. Norwood FL, Harling C, Chinnery PF, Eagle M, Bushby K, Straub V. Prevalence of genetic muscle disease in Northern England: in-depth analysis of a muscle clinic population. Brain 2009;132:3175-3186.

8. Harper P. Myotonic Dystrophy, 3rd ed. London: W.B. Saunders, 2001.

9. Hilbert JE, Ashizawa T, Day JW, et al. Diagnostic odyssey of patients with myotonic dystrophy. J Neurol 2013;260:2497-2504.

10. Kamsteeg EJ, Kress W, Catalli C, et al. Best practice guidelines and recommendations on the molecular diagnosis of myotonic dystrophy types 1 and 2. Eur J Hum Genet 2012;20:1203-1208.

11. Leferink M, Wong DPW, Cai S, et al. Robust and accurate detection and sizing of repeats within the DMPK gene using a novel TP-PCR test. Sci Rep 2019;9:8280.

12. Warner JP, Barron LH, Goudie D, et al. A general method for the detection of large CAG repeat expansions by fluorescent PCR. J Med Genet 1996;33:1022-1026.

13. Zhao M, Lee CG, Law HY, Chong SS. Enhanced Detection and Sizing of the HTT CAG Repeat Expansion in Huntington Disease Using an Improved Triplet-Primed PCR Assay. Neurodegener Dis 2016;16:348-351.

14. Lyon E, Laver T, Yu P, et al. A simple, high-throughput assay for Fragile $X$ expanded alleles using triple repeat primed PCR and capillary electrophoresis. J Mol Diagn 2010;12:505-511.

15. Zhao M, Cheah FSH, Chen M, Lee CG, Law HY, Chong SS. Improved high sensitivity screen for Huntington disease using a one-step triplet-primed PCR and melting curve assay. PLoS One 2017;12:e0180984.

16. Lian M, Rajan-Babu IS, Singh K, Lee CG, Law HY, Chong SS. Efficient and highly sensitive screen for myotonic dystrophy type 1 using a one-step triplet-primed PCR and melting curve assay. J Mol Diagn 2015;17:128-135.

17. Teo CR, Law HY, Lee CG, Chong SS. Screening for CGG repeat expansion in the FMR1 gene by melting curve analysis of combined 5' and 3' direct triplet-primed PCRs. Clin Chem 2012;58:568-579.

18. Saavedra-Matiz CA, Isabelle JT, Biski CK, et al. Cost-effective and scalable DNA extraction method from dried blood spots. Clin Chem 2013;59:1045-1051.

19. Falk M, Vojtiskova M, Lukas Z, Kroupova I, Froster U. Simple procedure for automatic detection of unstable alleles in the myotonic dystrophy and Huntington's disease loci. Genet Test 2006;10:85-97.

20. Charif D, Lobry JR. SeqinR 1.0-2: A Contributed Package to the R Project for Statistical Computing Devoted to Biological Sequences Retrieval and Analysis. In: Bastolla U, Porto M, Roman HE, Vendruscolo 
medRxiv preprint doi: https://doi.org/10.1101/2021.01.11.21249609; this version posted January 13, 2021. The copyright holder for this preprint (which was not certified by peer review) is the author/funder, who has granted medRxiv a license to display the preprint in perpetuity.

It is made available under a CC-BY-ND 4.0 International license .

M, eds. Structural Approaches to Sequence Evolution: Molecules, Networks, Populations. Berlin, Heidelberg: Springer Berlin Heidelberg, 2007: 207-232.

21. Dwight $Z$, Palais R, Wittwer CT. UMELT: prediction of high-resolution melting curves and dynamic melting profiles of PCR products in a rich web application. Bioinformatics 2011;27:1019-1020.

22. Diaz-Papkovich A, Anderson-Trocme L, Ben-Eghan C, Gravel S. UMAP reveals cryptic population structure and phenotype heterogeneity in large genomic cohorts. PLoS Genet 2019;15:e1008432.

23. Weiss RB, Vieland VJ, Dunn DM, Kaminoh Y, Flanigan KM, United Dystrophinopathy P. Longrange genomic regulators of THBS1 and LTBP4 modify disease severity in duchenne muscular dystrophy. Ann Neurol 2018;84:234-245.

24. Marnetto D, Huerta-Sánchez E. Haplostrips: revealing population structure through haplotype visualization. Methods in Ecology and Evolution 2017;8:1389-1392.

25. Lian M, Law HY, Lee CG, Chong SS. Defining the performance parameters of a rapid screening tool for myotonic dystrophy type 1 based on triplet-primed PCR and melt curve analysis. Expert Rev Mol Diagn 2016;16:1221-1232.

26. Tan VJ, Lian M, Faradz SMH, Winarni TI, Chong SS. A Single Common Assay for Robust and Rapid Fragile X Mental Retardation Syndrome Screening From Dried Blood Spots. Frontiers in genetics 2018;9:582.

27. Sontag MK, Lee R, Wright D, Freedenberg D, Sagel SD. Improving the Sensitivity and Positive Predictive Value in a Cystic Fibrosis Newborn Screening Program Using a Repeat Immunoreactive Trypsinogen and Genetic Analysis. J Pediatr 2016;175:150-158 e151.

28. Tang H, Kirkness EF, Lippert C, et al. Profiling of Short-Tandem-Repeat Disease Alleles in 12,632 Human Whole Genomes. Am J Hum Genet 2017;101:700-715.

29. Musova Z, Mazanec R, Krepelova A, et al. Highly unstable sequence interruptions of the CTG repeat in the myotonic dystrophy gene. Am J Med Genet A 2009;149A:1365-1374.

30. Santoro M, Masciullo M, Silvestri G, Novelli G, Botta A. Myotonic dystrophy type 1: role of CCG, CTC and CGG interruptions within DMPK alleles in the pathogenesis and molecular diagnosis. Clin Genet 2017;92:355-364.

31. Botta A, Rossi G, Marcaurelio M, et al. Identification and characterization of 5 ' CCG interruptions in complex DMPK expanded alleles. Eur J Hum Genet 2017;25:257-261.

32. Ballester-Lopez A, Koehorst E, Almendrote $M$, et al. A DM1 family with interruptions associated with atypical symptoms and late onset but not with a milder phenotype. Hum Mutat 2020;41:420-431.

33. Cumming SA, Jimenez-Moreno C, Okkersen K, et al. Genetic determinants of disease severity in the myotonic dystrophy type 1 OPTIMISTIC cohort. Neurology 2019;93:e995-e1009.

34. Pesovic J, Peric S, Brkusanin M, Brajuskovic G, Rakocevic-Stojanovic V, Savic-Pavicevic D. Molecular genetic and clinical characterization of myotonic dystrophy type 1 patients carrying variant repeats within DMPK expansions. Neurogenetics 2017;18:207-218.

35. Volk AE, Kubisch $\mathrm{C}$. The rapid evolution of molecular genetic diagnostics in neuromuscular diseases. Curr Opin Neurol 2017;30:523-528. 
Table 1. Summary of blinded scoring of melt profiles from control samples with homozygous DMPK diplotypes and known DM1 patient samples.

\begin{tabular}{lccccc} 
& \multicolumn{4}{c}{ Blinded Score $^{\dagger}$} & Total \\
\cline { 2 - 5 } & Normal & Intermediate & Premutation & Expanded & - \\
\hline$(-+-)$ diplotype & $15(100 \%)$ & - & - & - & 15 \\
$(+++)$ diplotype & $15(100 \%)$ & - & - & & 15 \\
$(---)$ diplotype & $2(13 \%)$ & $9(60 \%)$ & $4(27 \%)$ & $57(100 \%)$ & 57 \\
Known DM1 & - & - & - & 5 \\
\hline
\end{tabular}

${ }^{\dagger}$ Expected range for $(\mathrm{CTG})_{\mathrm{n}}$ in the $(-+-)$ haplotype $=5$, in the $(+++)$ haplotype $=8-17$ and in the $(---)$ haplotype $=18-35$. 
medRxiv preprint doi: https://doi.org/10.1101/2021.01.11.21249609; this version posted January 13, 2021. The copyright holder for this preprint (which was not certified by peer review) is the author/funder, who has granted medRxiv a license to display the preprint in perpetuity. It is made available under a CC-BY-ND 4.0 International license.

Table 2. Summary of blinded scoring from control samples and dried blood spots.

Consensus of Blinded Scoring $\dagger$

\section{Controls \\ (allele1::allele2)}

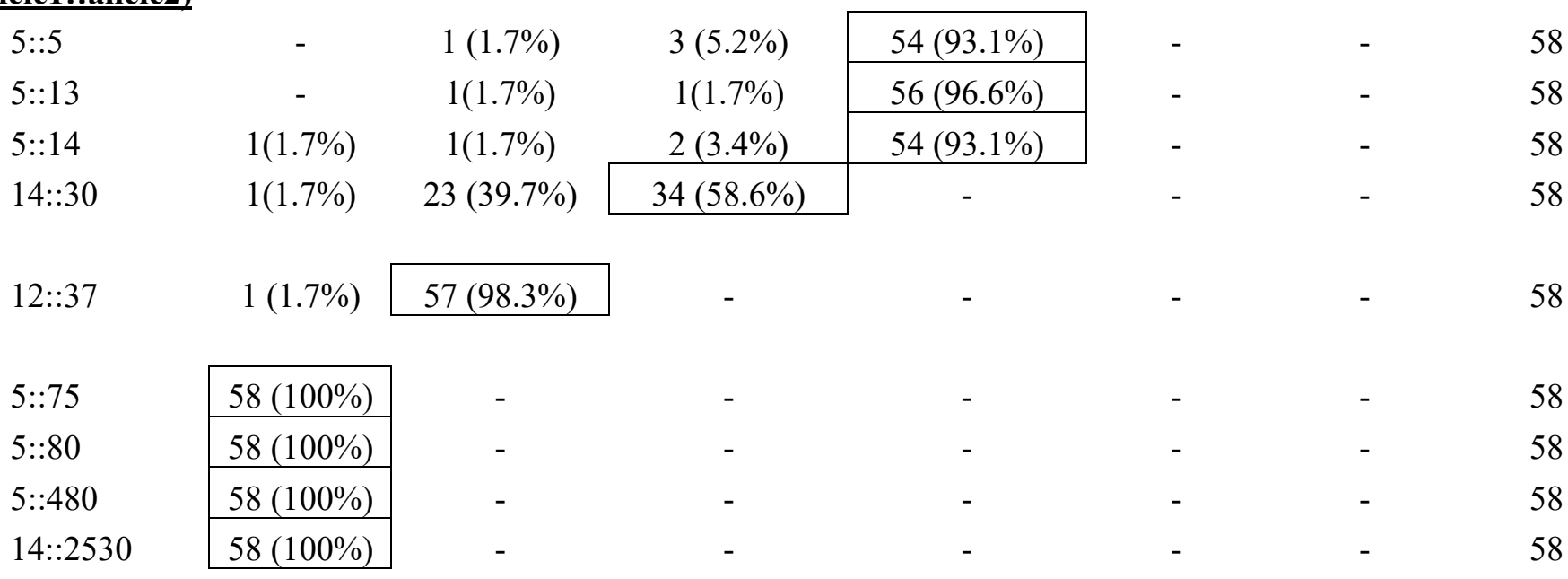

\section{$\underline{\text { Study samples }}$}

DBS

16

$\uparrow$ Boxed fields represent the true classification for each control sample. 


\section{FIGURES AND FIGURE LEGENDS}

A

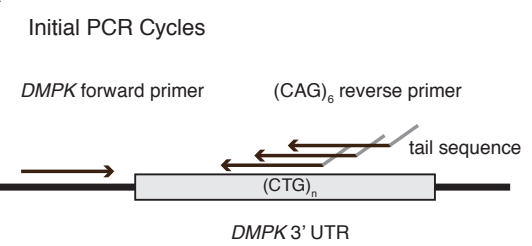

Later PCR Cycles

10:1 molar ratio of tail primer :: $(\mathrm{CAG})_{6}$ reverse primer

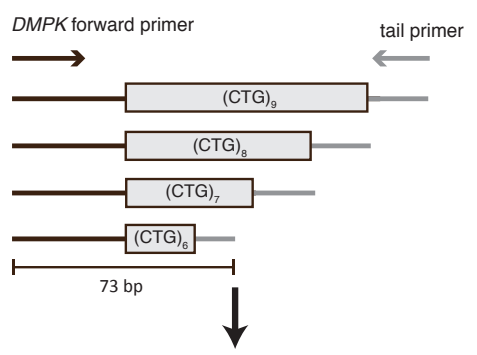

High Resolution Melt analysis
B
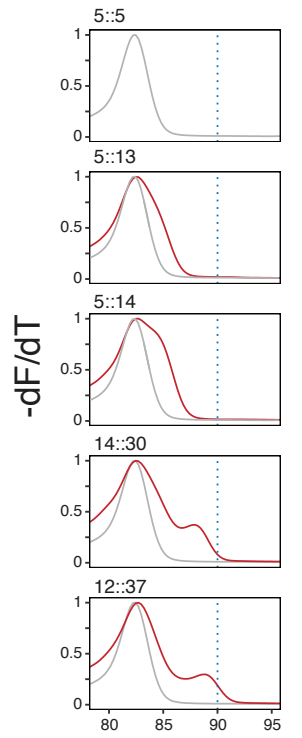
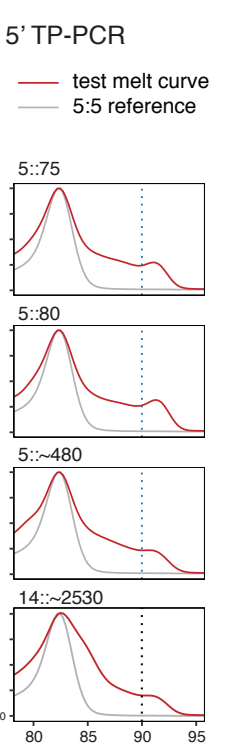

Temperature $\left({ }^{\circ} \mathrm{C}\right)$
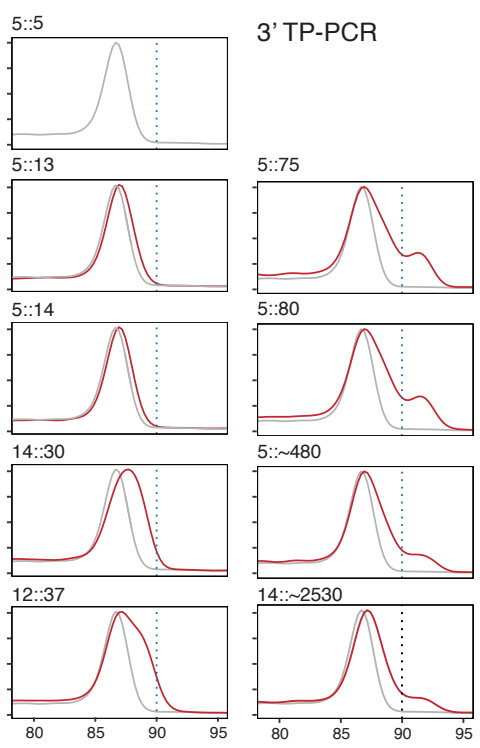

$5:: 80$

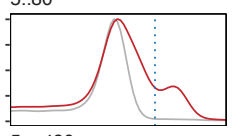

$5:: \sim 480$
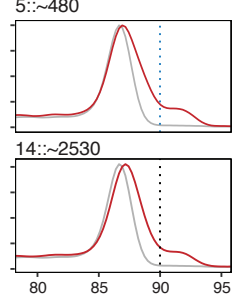

Figure 1. Assay design for DMPK TP-PCR melt curve analysis.

(A) Location of the unique DMPK forward primer and the $(\mathrm{CAG})_{6}$ reverse / tail primers used to generate a nested set of amplicons. (B) Normalized -dF/dT melt curves from the 5' TP-PCR and 3' TP-PCR reactions using control samples with increasing CTG repeat lengths. The melt curve from the 5:5 homozygous sample (gray curve) is plotted with melt curve from each test sample (red curve). The CTG repeat sizes of the alleles in the test samples are indicated above each plot. 
A
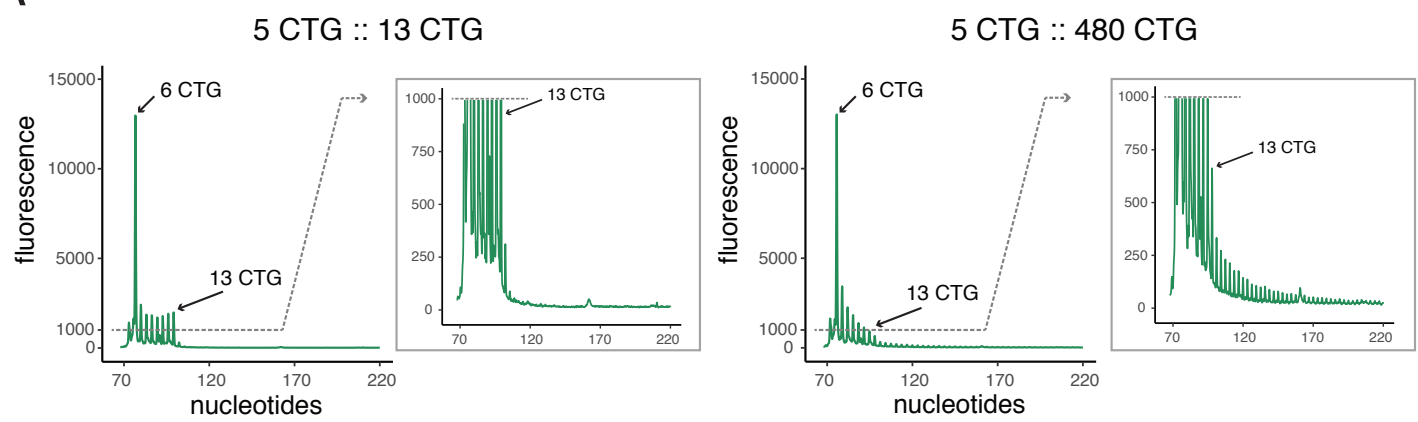

B

Predicted melt curve from 5 CTG :: 13 CTG primer extension

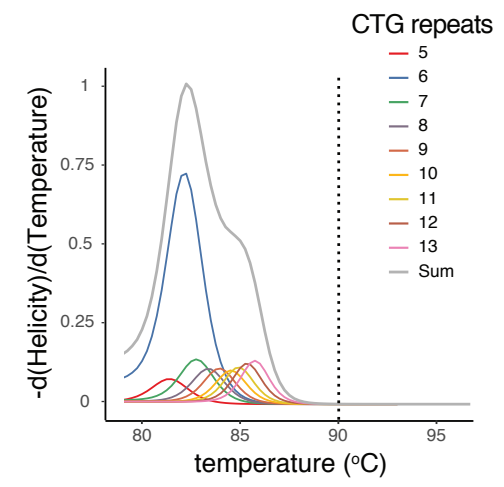

C

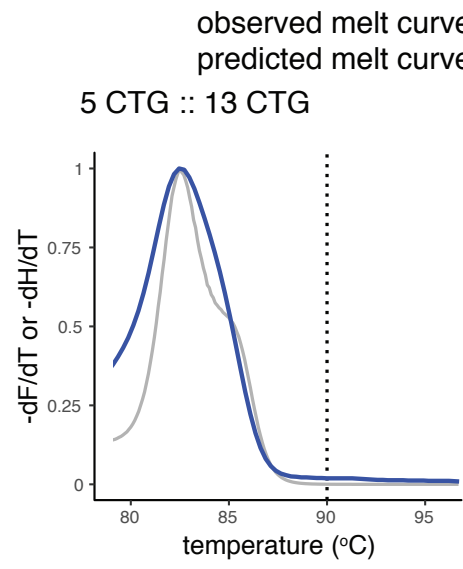

observed melt curve $=$

$$
=
$$

5 CTG :: 480 CTG

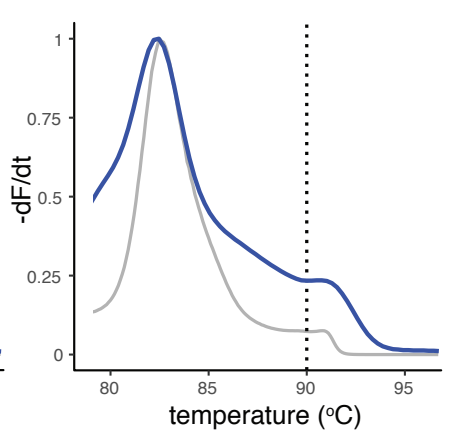

Figure 2. DMPK TP-PCR melt curve reconstruction.

(A) Electropherograms from primer extensions using a FAM-labeled DMPK forward primer with post-TP-PCR products from a normal $(5:: 13)$ and affected $(5:: 480)$ individual. For each electropherogram, the boxed inset shows a zoomed y-axis. (B) Predicted - $\mathrm{dH} / \mathrm{dT}$ melt curve (gray) summarized from the individual curves (colored) in proportion to their peak heights observed in (B) for the 5::13 sample. (C) The observed -dF/dT melt curves (blue) plotted with the normalized $-\mathrm{dH} / \mathrm{dT}$ predicted curves (gray) for the $5:: 13$ and $5:: 480$ samples. 
A
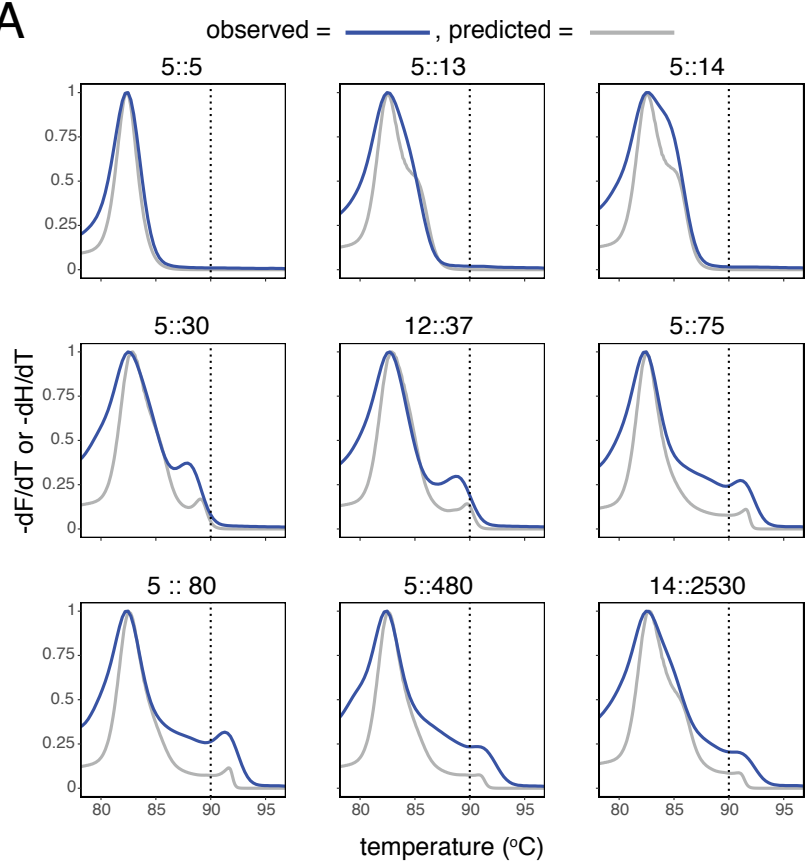

B

Template DNA (ng) $20 \quad 2 \quad 0.2 \quad 0.02$
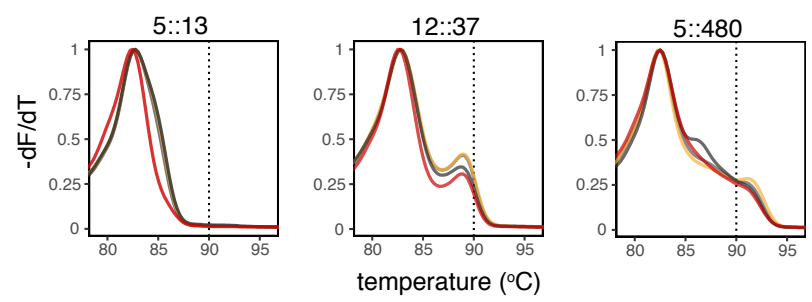

Figure 3. -dF/dT melt curves from normal control and DM1 patient samples.

(A) Normalized -dF/dT melt curves from known CTG repeat lengths (blue) plotted against their predicted $-\mathrm{dH} / \mathrm{dT}$ curves (gray). TP-PCR reactions used $2.0 \mathrm{ng}$ of genomic DNA and the predicted melt curve were reconstructed from the fragment ratios observed by primer extension with post-TP-PCR products. (B) -dF/dT melt curves produced by TP-PCR using serially diluted amounts of human genomic DNA. 
A

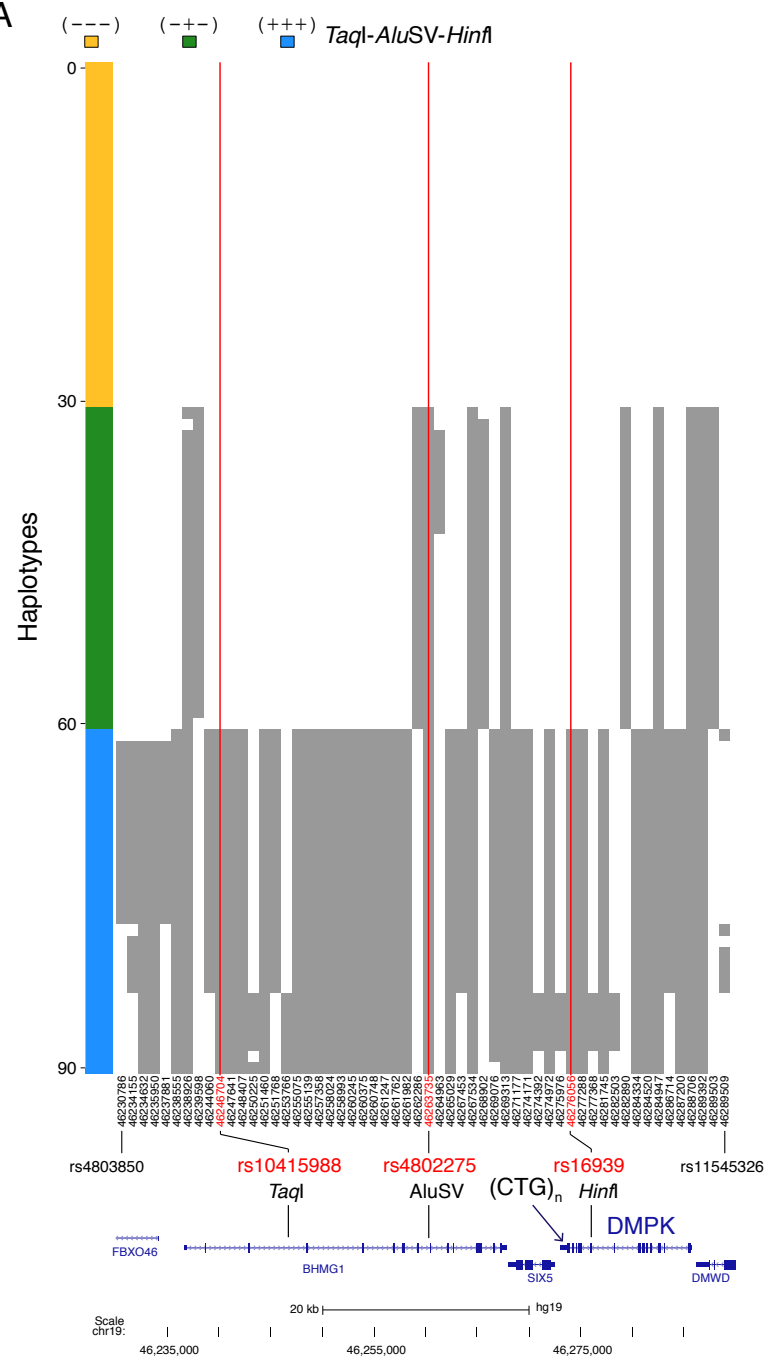

B

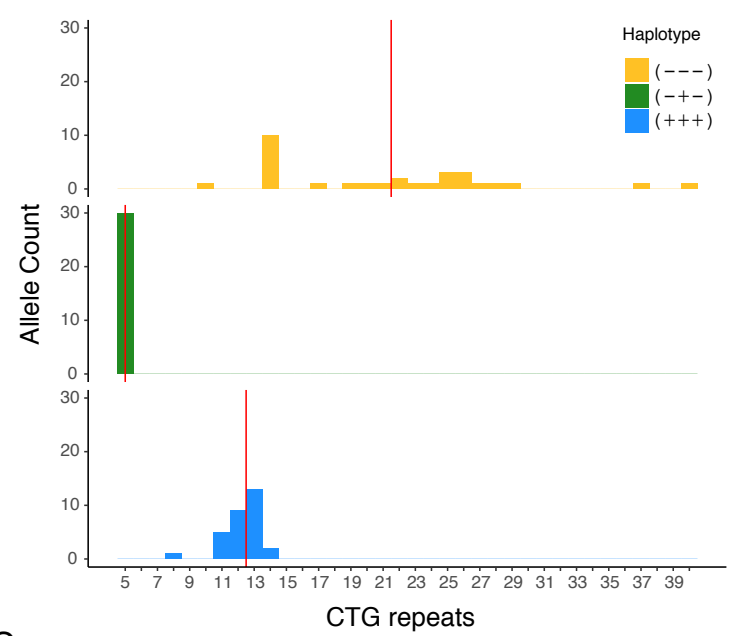

C
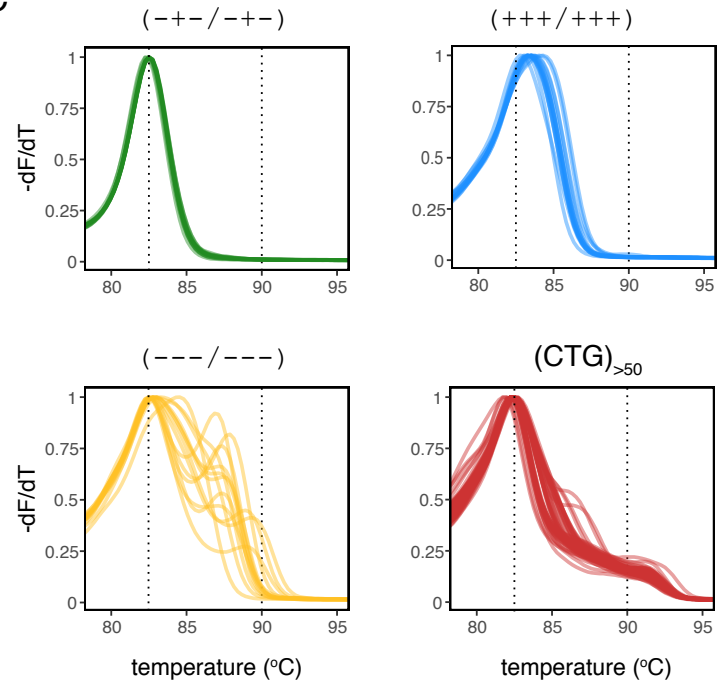

Figure 4. Haplotype and Melt analysis of common DMPK diplotypes and known DM1 patient samples.

(A) Haplostrips plot of the DMPK region (chr19: 46230001-46290000, hg19) using 90 sorted and clustered haplotypes from 45 control samples. Phased haplotypes are in rows and SNPs with a minor allele frequency $\geq 0.15$ are in columns. The alleles are colored relative to the $(--)$ haplotype group with white as the reference allele and grey as the alternate allele for each of the 56 polymorphic sites. Vertical red lines indicate the positions of the original Taql (rs10415988) and Hinfl (rs16939) polymorphisms, as well as a SNP (rs4802275) in complete LD with the Alu structural variant. (B) Plot of CTG repeat numbers observed for the 15 control samples within each of the three homozygous diplotype groups. Red vertical line indicates the median CTG repeat number in each diplotype group. Expected range for $(C T G)_{n}$ in the $(-+-)$ haplotype $=5$, in the $(+++)$ haplotype $=8-17$ and in the $(---)$ haplotype $=18-35$. (C) $-\mathrm{dF} / \mathrm{dT}$ melt curves from 15 individual samples in each of the three common diplotype groups seen in human populations (green $(-+-)$, blue $(+++)$, and yellow $(---)$, see Supplemental Table S1. In each group, diplotype colors and labels are the same as in (B), and melt curves from 57 clinically diagnosed DM1 patients are plotted in red. 
medRxiv preprint doi: https://doi.org/10.1101/2021.01.11.21249609; this version posted January 13, 2021. The copyright holder for this preprint (which was not certified by peer review) is the author/funder, who has granted medRxiv a license to display the preprint in perpetuity.

It is made available under a CC-BY-ND 4.0 International license .

A

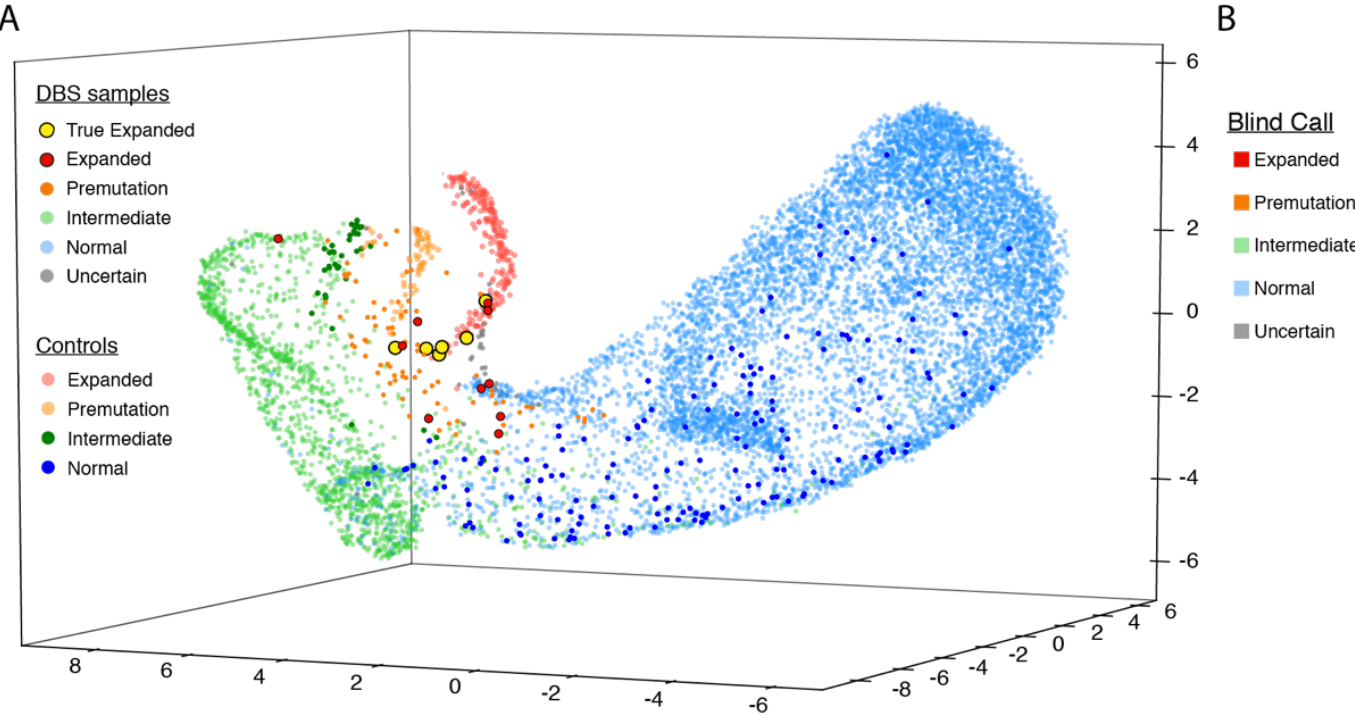

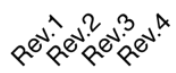

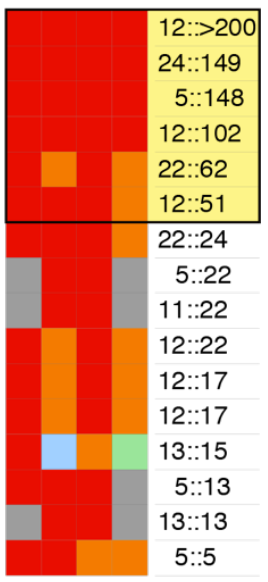

Figure 5. UMAP clustering and variability of blinded review of melt curves from DBS. (A) The -dF/dT data from $87.25^{\circ} \mathrm{C}$ to $96.70{ }^{\circ} \mathrm{C}$ was clustered by UMAP and visualized as a 3-dimensional representation. 10,097 DBS samples, and 232 expanded $(5:: 75,5:: 80,5:: 480$, and $5:: 2530), 56$ premutation (12::37), 44 intermediate $(14:: 30)$, and 170 normal $(5:: 5,5:: 13$, and $5:: 14)$ control melt profiles were used with sample points colored by the consensus call of blinded reviewers. (B) Heatmap of individual calls from the four blinded reviewers and the final sized CTG repeat size (allele 1 :: allele 2) by direct PCR or the Amplidex® DM1 Dx Kit for each sample with consensus call of "expanded" is shown, with the true positives boxed in yellow. 
A

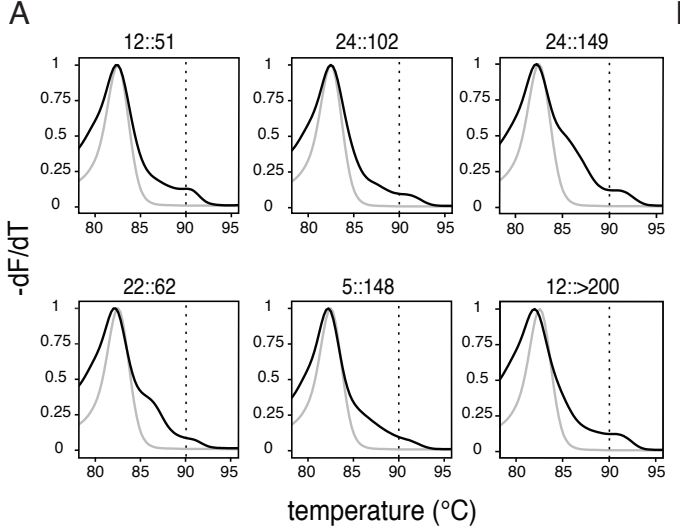

B

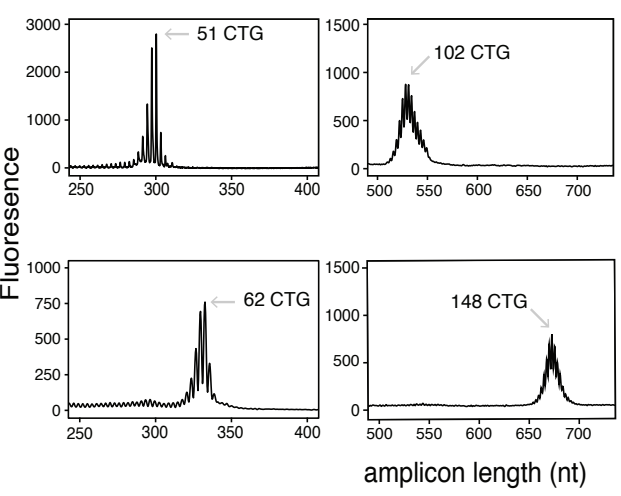

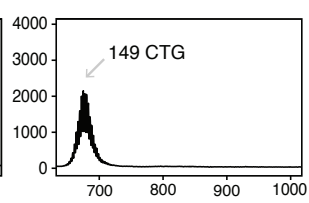

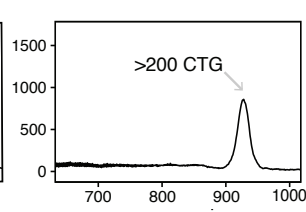

Figure 6. Melt curve profiles and sizes for DBS samples with CTG repeats $\geq \mathbf{5 0}$.

(A) Normalized -dF/dT melt curves for the 6 size-confirmed expanded samples (black), plotted with normal (5::5) control (gray). (B) Capillary electropherograms of the 6 expanded DBS samples amplified with direct sizing PCR (51 and 62 CTG repeats) or using the Amplidex® DM1 Dx Kit (102, 148, 149 and >200å CTG repeats). 